\title{
Wildlife Utilization in China
}

\author{
by \\ Charles E. Greer, Ph.D.(Washington) \\ $\&$ \\ Robin W. Doughty, Ph.D.(California at Berkeley) \\ Department of Geography, University of Texas, Austin, Texas 78712, U.S.A.
}

\section{INTRODUCTION}

Europeans knew relatively little about the flora and fauna of China until the middle of the nineteenth century. Some adventurers, such as Marco Polo, and various merchants, had gathered desultory, often inaccurate, and mostly derivative, information about plants and animals in earlier times; however, with the explorations of the Abbé Armand David, who was stationed in China from 1864 to 1872 , and other competent naturalists after him, knowledge was systematically organized about the numerous and varied biota of the Orient-particularly in the thinly-settled areas of western China. Reports of impressive herds of ungulates and predatory carnivores inhabiting interior plateaus, including the highlands of western Szechuan (Pen, 1962) and other grassland areas to the south in India, suggested an abundant wildlife comparable with that of African savannas (Allen, 1938; Tate, 1947; Schaller \& Simon, 1970).

China's fauna is essentially palaearctic (Eurasia north of the Tropic of Cancer) in origin (Darlington, 1957), having evolved in aboriginal deciduous forestlands in the moist east, and in steppe uplands in the more arid west and north (Köppen climatic classification: $\mathrm{C}$ and $\mathrm{D}$ versus $\mathrm{B}$ and $\mathrm{E}$ ). In recent centuries, animal assemblages have been restricted in distribution and simplified by human settlement and the expansion of agriculture necessary to support a growing rural population. Wild mammals in China and India have, therefore, suffered numerical declines from loss of habitat, human persecution, and competition from domestic stock (Seshadri, 1969).

While traditional utilization of wild animals for meat, hides, and medicinal and other purposes, has continued to flourish in China under the Communist government, the incipient science of wildlife management, fashioned originally after a Soviet model, has aimed at improving the economic returns from wild and semi-wild animals. In particular, it has concentrated upon the rehabilitation and relocation of native fauna and upon the acclimatization of exotic species. Chinese biologists seek to maximize returns from animals through the establishment of hunting seasons, the eradication of predators, setting up wildlife reserves and restoration programmes, and the development of environmental controls. There is much greater emphasis on economic uses of wildlife than on the kinds of recreational needs that have largely characterized programmes in the West, and especially in the United States (e.g. Leopold, 1933).

China's modern policy for wildlife, stated in deceptively simple terms, aims to protect, raise, and hunt, certain animals, to protect conscientiously all useful mammals and birds, and to eliminate economically harmful and dangerous animals (People's Daily, Peking, 10 Nov. 1961). Strategies to implement this policy involve three basic, interrelated elements: (1) the hunting and management of wild species, particularly populations of fur-bearers, (2) the cropping and farming of native and foreign game-mammals and birds on a sustained basis, and (3) the husbandry of selected tame fauna. Table I gives some indication of the main products and uses of a wide range of the more economically valuable North Asian Mammals.

\section{WILDLIFE HUNTING AND MANAGEMENT}

Several hundred thousand Chinese hunt annually, and their activities are reported as an integral part of the nation's agricultural productivity. Hunting for commercial purposes is well established in many of the less-populated autonomous regions in China's north, west, and south-west provinces that tend to be occupied by traditionally non-agricultural peoples. When wildlife populations warrant a concerted effort, teams of hunters from local collectives shoot and trap selected species in order to supplement their diet, provide extra income from the sale of pelts and other animal products, and to establish a reputation for productivity. Individuals may also engage in seasonal hunting as an occupation secondary to agriculture, 
TABLE I

Economically Useful North Asian Mammals*

\begin{tabular}{|c|c|c|}
\hline Mammal & Product & Use \\
\hline Wild Sheep & meat, skins & leather, rugs \\
\hline Sika Deer & horns & medicinal \\
\hline Roe Deer & horns & medicinal \\
\hline Musk Deer & musk gland & perfumes \\
\hline Elk & meat, skins, horns & food, apparel, medicinal \\
\hline Mongolian Gazelle & meat, skins & food, rugs, apparel \\
\hline Goral & skins & rugs \\
\hline Tiger & skins, bones & rugs, medicinal \\
\hline Leopards & skins & rugs \\
\hline Other Felids (Lynx, etc.) & skins & apparel \\
\hline Mustelids (Martins, Weasel, Otter, etc.) & skins & apparel \\
\hline Bear & gall bladder, skins & medicinal, rugs \\
\hline Wolf & skins & rugs \\
\hline Fox & skins & apparel \\
\hline Sciurids (various Squirrels, Marmots, etc.) & skins & apparel \\
\hline
\end{tabular}

*Sources: Sowerby $(1914,1918)$, Allen $(1938,1940)$, Tate (1947).

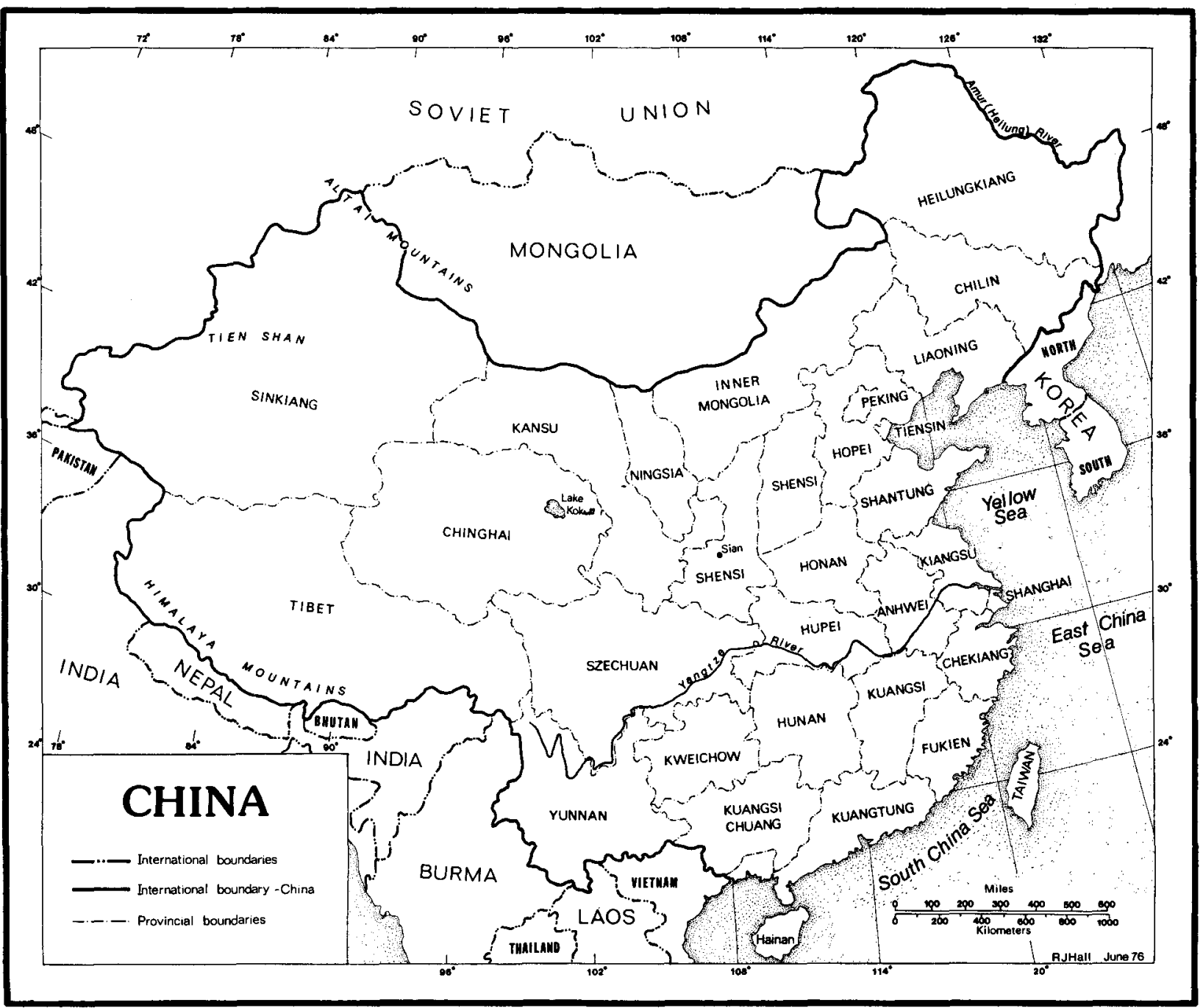

FIG. 1. Map of China indicating the provinces, adjacent countries, etc. In the middle is Lake Kokonor. 


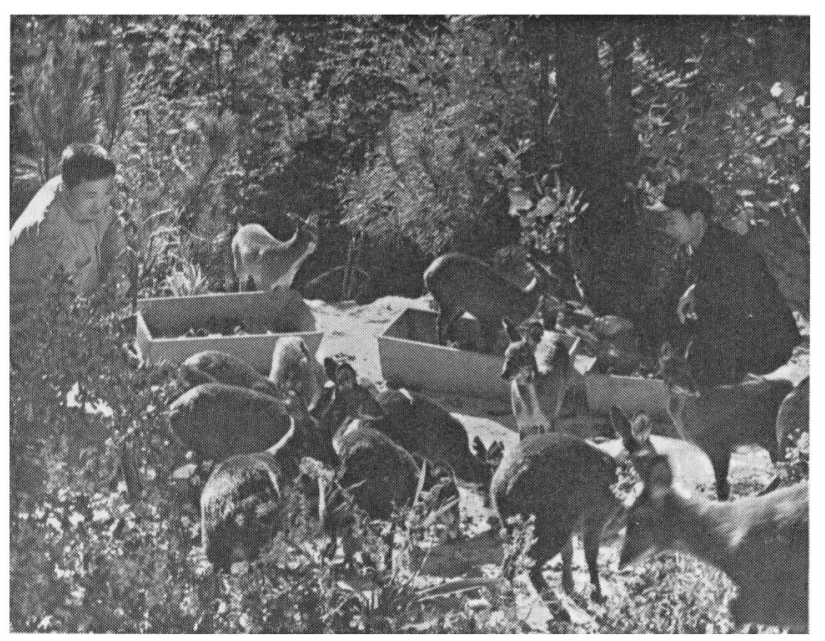

FIG. 2. Musk Deer on experimental farm, Shensi Province (by courtesy of China Pictorial, March 1973, p. 44).

and they are free to dispose of their bag as they desire. Income from hunting is frequently higher than from an equivalent amount of farm labour, and central government leaders praise the communes which increase their revenues from hunting wild animals.

Comprehensive national game-harvest figures have not been available, although scattered references to provincial totals occasionally appear. Hunters in the northwestern province of Chinghai, for example, produced 1,500 tonnes of game, 400,000 pelts and hides, and 500,000 wild birds, from 1970 to 1972. The province also supplied to the central government 1,000 kilos of antlers, taken mostly from wild deer (New China News Agency*, Sining, 28 Feb. 1973). Fig. 1 is a map of the People's Republic of China indicating the provinces etc., and adjacent states for purposes of orientation.

Several species of deer (family Cervidae), notably the Roe Deer, Sika or Spotted Deer, and Red Deer, are hunted to supply important medicinal and industrial products in addition to meat and hides. Processed antlers in velvet, testes and tails of male deer, and dried foetuses, are believed to hold medicinal properties. The small and primitive Musk Deer (Fig. 2), of the subfamily Moschinae, which is found in the forested uplands in central and north-east Asia (from Mongolia and Korea south-west to Tibet, see Fig. 1), commands a high cash value because of the musk found in the abdominal pouch of grown males (Fig. 3). Estimates of the numbers of animals shot, hunted with dogs, or snared, have risen from 10-15,000 (Sowerby, 1925 ) to approximately 100,000 annually (Harris, 1947; Whitehead, 1972). The 25-30 grams of musk per animal provide the basic blend and harmony to perfume and soap, and complement three other

* Abbreviated henceforth to NCNA. natural animal products-castor, ambergris, and civet - that are important in the cosmetic industry.

Waterfowl and upland game-birds provide meat and feathers which are sold on national and international markets. Over 10,000 geese may be captured in the course of a spring near Sian, in the northern province of Shensi, to supply feathers for industrial and ornamental use. Several scores of tonnes of ducks' down are reportedly exported from north China annually. Cheng Tso-hsin (1964) lists 56 species (belonging to 10 orders and 13 families) of birds whose plumage, flesh, or medicinal qualities, are economically significant. He notes, for example, that two tonnes of swans' down were worth the equivalent of a tractor in exchange at that time, as swans' down is exported to Japan and several European countries. Other waterbirds, such as the common crane, are killed in large numbers for valuable flight feathers and undertail coverts; also, the plumage of at least ten different hawks and eagles is used in the manufacture of fans and for ornamental trim that is sold on markets in other Asian countries (Ibid.). Small passerine birds of bright hue and pleasing song are trapped for cage purposes. Some of these, together with certain raptors and waterfowl, persecuted for plumage (the Japanese Crane, for example), have suffered significant losses, and experts are beginning to express concern about the threat of extinction.

One way of increasing the returns from hunting animal wildlife is to reduce the number of creatures that prey upon populations of wild animals and also upon domestic stock. Elimination of canids and felids, regarded as harmful to desirable wild animals, livestock, or humans' safety, and whose pelts are economically useful, is a stated goal of Chinese management policy. The Tiger, for example, holds a

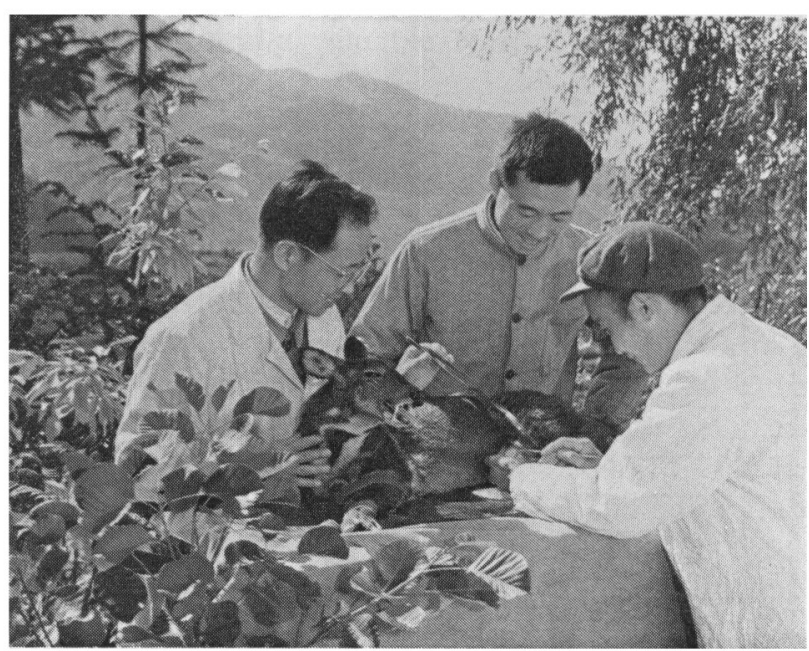

FIG. 3. Extracting musk from living Musk Deer (by courtesy of China Pictorial, March 1973, p. 45). 
unique place in Oriental traditions of myth and folklore. It decorates bronze and pottery vessels back to the Ch'in (221 B.C.) and Han (206 B.C.) dynasties, and the literature of northern peoples is full of tales of the Tiger as Ta Sheng, the Great Spirit, who symbolizes strength and courage (Sowerby, 1933). Tiger bones, blood, and flesh, are invaluable medicinal items for Chinese people, and the body of China's 'King of beasts' is more precious than its hide (Sowerby, 1940).

Nevertheless, deference for the Tiger has not prevented it from being listed with other harmful or dangerous carnivores that deserve to be eliminated, and the tiger hunter retains the role of a hero in modern China. One expedition to Koyin County, Kuangtung, was led by a 77-years-old veteran who was renowned for his claim of killing 170 Tigers; he killed four more in 1962 (NCNA, 11 June 1962).

Three races of Leopard continue to be heavily persecuted because of the judgement that they are harmful to stock, unsafe to humans, and have desirable pelts. Despite a Soviet ban in 1956 on Leopard hunting along the Amur River border with northeast China, over 50 Leopards have been killed and an additional 20 trapped in the past 20 years, so that fewer than 50 animals were censused as remaining there in the winter 1972-73 (Abramov \& Pikunov, 1974). Little information is available about the status of southern China's Clouded Leopard, but concern is being expressed over the ultimate fate of her third species of big cat, the Snow Leopard, which occurs in the high mountains from the Himalayas northwards to the Altai, but is hard pressed for its pelt (Paradiso, 1972).

In parts of China where wild animals are hunted, they may also be kept in enclosures under controlled

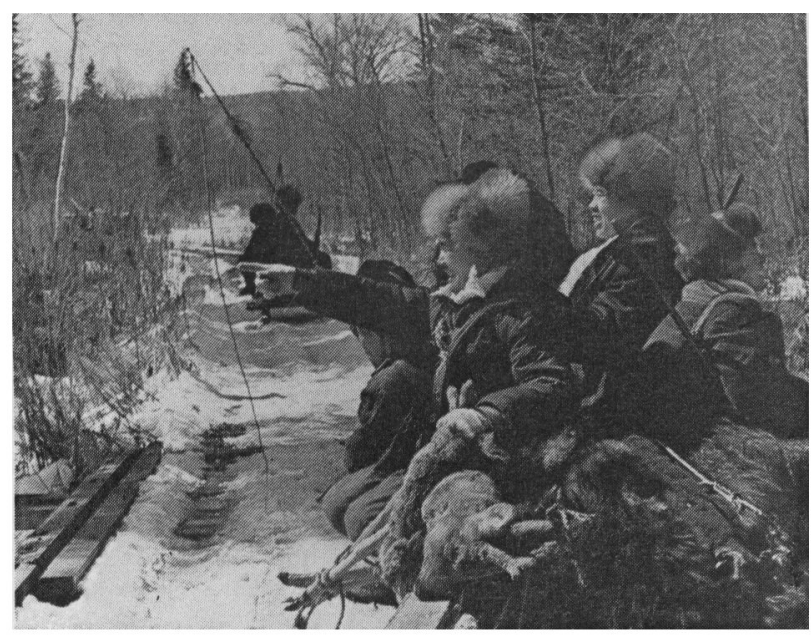

FIG. 4. National minority hunters in north-east China (by courtesy of China Reconstructs, August 1972, p. 46.)

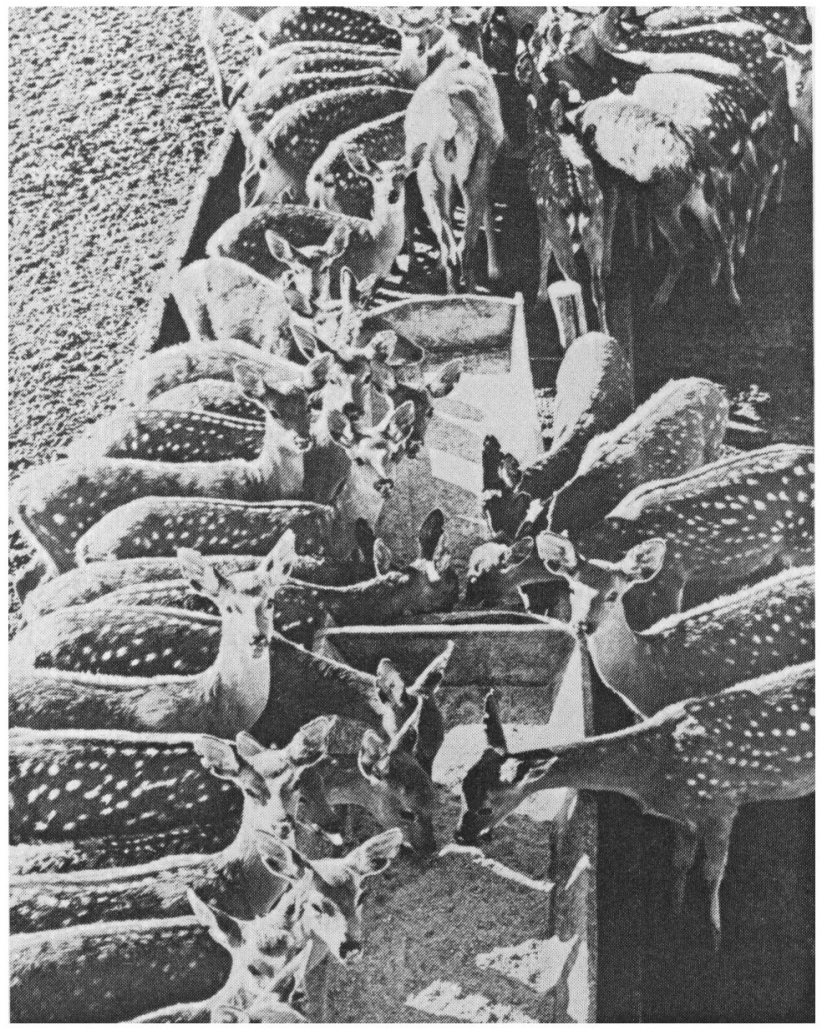

Frg. 5. Yearling Sika Deer feeding, Heilungkiang Province (by courtesy of China Reconstructs, January 1972, p. 34.)

conditions. The people of the Olunchun national minority in northern Inner Mongolia Autonomous Region (now Heilungkiang, the most northeasterly province of China) are widely publicized as a group combining a traditional hunting life (Fig. 4) with raising animals (Fig. 5). The Olunchun, who number about 2,000 and comprise China's smallest national minority, were formerly nomadic forest hunters who pursued deer, bear, and Wild Boar. During collectivization in the 1950s, they were settled in villages, where agricultural produce began to supplement game, and they began commerce in skins and animal products of pharmaceutical significance (Wang, 1955; Lin \& Shen, 1957). The value of wild animal products per active hunter among the Olunchuns in 1955 was about 1,000 yuan (\$400), which was considerably more than the national average income from agriculture at that time. In addition to Roe Deer, Wild Boar, and artificially bred Red Deer, the Olunchun people harvested a total of 30,000 Grey Squirrels in 1965 (NCNA, 25 September 1965).

\section{ACCLIMATIZATION PROGRAMMES AND FARMING}

Evidence of the economic orientation of China's wildlife policies is found in the number of exotic furbearing species which have been held captive on farms 
or have been released into the wild to build up populations that can be cropped. In this respect, the Chinese have followed the lead of Russian scientists who have utilized Nutria and other imported animals 'for the reconstruction of Soviet fauna' (Pavlov, 1966). Between 1930 and 1932, over 2,500 Nutria were carried into the USSR from Argentina, the United Kingdom, and Germany, and became established in suitable locations in Georgia, Armenia, parts of Turkmenia, and elsewhere, where they provided an offtake which was recently assessed at 100,000 pelts annually.

In a similar manner, between 1927 and 1953, about 117,000 Muskrats (many from Canada) and other North American animals, such as Raccoon (in 1936) and Mink (into Karelia in 1934), were released in different places in the Soviet Union, eventually to flourish and spread. The Raccoon has not done so well; however, an organization of state Muskrat farms was set up in 1943 to conduct commerce in this exotic rodent, and the Muskrat has risen to second or third place in the Soviet fur trade (Korsakov, 1966). It is estimated that the introduction of this foreign animal actually enriched the USSR wetland ecosystem by improving the habitat for other animals and by providing carnivorous predators with a reliable food resource (Curry-Lindahl, 1972). Soviet scientists have concluded that holarctic, rather than tropical, species which are able to adapt more fully and quickly to man-altered biotopes, appear most successful (Nasimovich, 1966).

In 1956 and 1957, Mink, Nutria, Muskrat, Beaver, and foxes, were carried from the Soviet Union into China and placed on farms in Kweichow, Chekiang, and several northern provinces. By 1959, seventy farms for these fur-bearing species were in operation, and additional animals on them included Sable, Badger, Martin, Otter, and Stoat.

Fur-bearing animals have also been redistributed within China. A mustelid, the Sable, native to Inner Mongolia and Sinkiang north of latitude 45 degrees, has been translocated farther east and raised in the provinces of Heilungkiang and Chilin (cf. Fig. 1). Species reared in captivity and released are strictly protected from illegal hunting ( NCNA, 26 Feb. 1959).

Mink-rearing appears to be one of the most successful programmes in fur production. Large numbers of Mink have been transferred from native habitats in north-central and north-east China to Mink farms in the west on the Chinghai Plateau where, after initial problems of adaptation, they were reportedly doing well in 1966 (NCNA, 30 Oct. 1966). In due course, more than 5,000 Mink pelts were being sold annually to the State from farms in Chinghai Province ( $N C N A$, 8 June 1972).
Mink carried into the Soviet Union from North America have supposedly "enriched the commercial fauna' of Siberia. More spectacular animals tested by the Russians include Wild Turkeys from America, Ostriches and Eland from Africa, and various pheasants from Asia. In Russia, interest in exotic wildlife has been extended beyond mammals and birds to include fishes and even insects, and the same appears to be the case also in China. Soviet biologists have successfully acclimatized two Chinese fishes, the White Amur and the Tolstol, to inland waters in the USSR, and have mixed the fish fauna of the Caspian and Aral Seas in order to increase catches. Nine introduced species of fishes are expected to cause a sixfold increase in the commercial returns from some freshwater fisheries in the USSR (Burmakin, 1966).

The simultaneous hunting, protection, and raising, of wild animals in China is well illustrated by 'farming' selected species, often in conjunction with hunting them. Reserves have been set aside for several species in their natural habitats, notably for Roe Deer in Inner Mongolia, Sinkiang, and Chinghai, and for Musk Deer in Szechuan, Shensi, and Chinghai. A practice exists of keeping and breeding deer, the Sika or Spotted Deer in particular (Fig. 5), in deer yards or in fenced portions of forests to insure a supply of antlers in the velvet. By 1930, about 5,500 deer were reported in confinement in the Far East (Flerov, 1952); the North China race of Sika may indeed have become extinct except on deer farms (Allen, 1940; Whitehead, 1972). Under the Communist regime, deer farming has continued to prosper. From experimental beginnings during the 1950 s, the number of deer raised annually in captivity had grown to 22,000 animals on 130 farms already in 1963 (NCNA, 13 Nov. 1963). By 1973 , it was reported that 1,300 deer were held on fourteen state farms in Chinghai Province alone, and it was stated that methods have been developed for removing the antlers from Roe Deer and the musk from Musk Deer without killing the animals (Flerov, 1952; Pen, 1962; NCNA, 28 Feb. 1973).

\section{ANIMAL HUSBANDRY}

Implementation of advances in animal husbandry received a major boost from the Sino-Mongolian economic and cultural cooperation agreement in 1952, which led to increased trade with China's agricultural heartland and to improvements for native Mongolian herd animals. Livestock improvements in China's neighbour, Mongolia, where animal husbandry is an ancient tradition, have included crossing native sheep with British breeds, horses with Siberian types, and cattle with Swiss bloodlines (Kislovsky, 1938). Nomadic herdsmen in the Altai and Tienshan uplands, within the Ili Kazakh Autonomous 'Chou' which occupies the northern part of Sinkiang Province, 


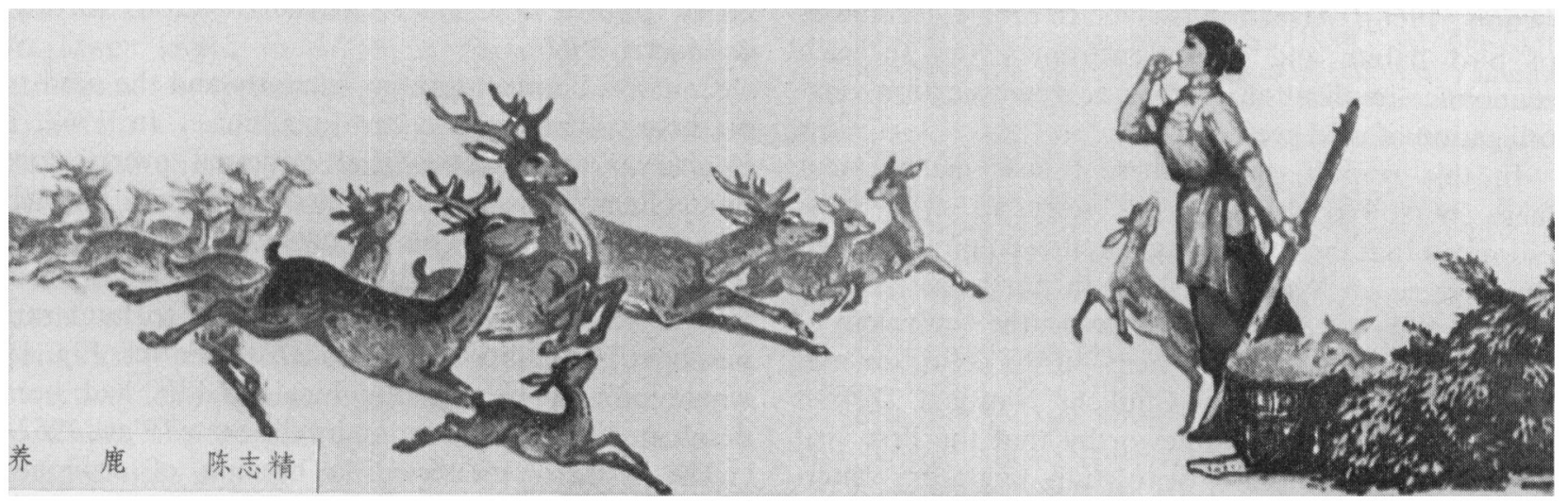

FIG. 6. Popular print entitled 'raising deer' : note fawn in basket.

have increased the numbers of horses, sheep, cattle, and goats, in recent decades. They have also improved the quality of stock by setting up breeding stations and bringing in new bloodstock (Chen, 1957). In particular, crosses of cattle with yaks have improved these important sources of milk and meat for the herding peoples of the area and for others throughout the Central Asian mountains and extending into Tibet. The live-weight of the hybrid from a cattle $\times$ yak cross, called Pien Niu, is one-fifth greater than that of cattle alone, and the hybrid produces a better carcass; moreover the milk yield of the female hybrid is higher than that from the pure-bred yak (NCNA, 11 Feb. 1965; Rouse, 1970; Cole \& Ronning, 1974).

It has been suggested that a special use be made of the Little Egret (family Ardeidae) in provinces where this 'white heron' occurs in the wild to the south of the Yangtze River (Cheng Tso-hsin, 1964). The Little Egret can be kept in close confinement for the purpose of securing nuptial dorsal plumes. Mention is made by Ali \& Ripley (1968) of a practice in India whereby egrets were, and possibly still are, kept in 'chicken coop' situations.

There is also a tradition of husbanding deer in China, as indicated above and in Fig. 6.

\section{WILDLIFE REFUGES}

Game preserves have long been maintained in various parts of China to protect economically important, scientifically interesting, or rare, animals (Schafer, 1968), and recently, for example, twelve preserves have been established in Chinghai Province -including the Bird Island Control Station, located on an island in Lake Kokonor (Fig. 7). Operated by the North-west Plateau Biological Research Institute and a Provincial Committee for Game Control, this station was established to preserve and study birds which migrate between northern and southern Asia

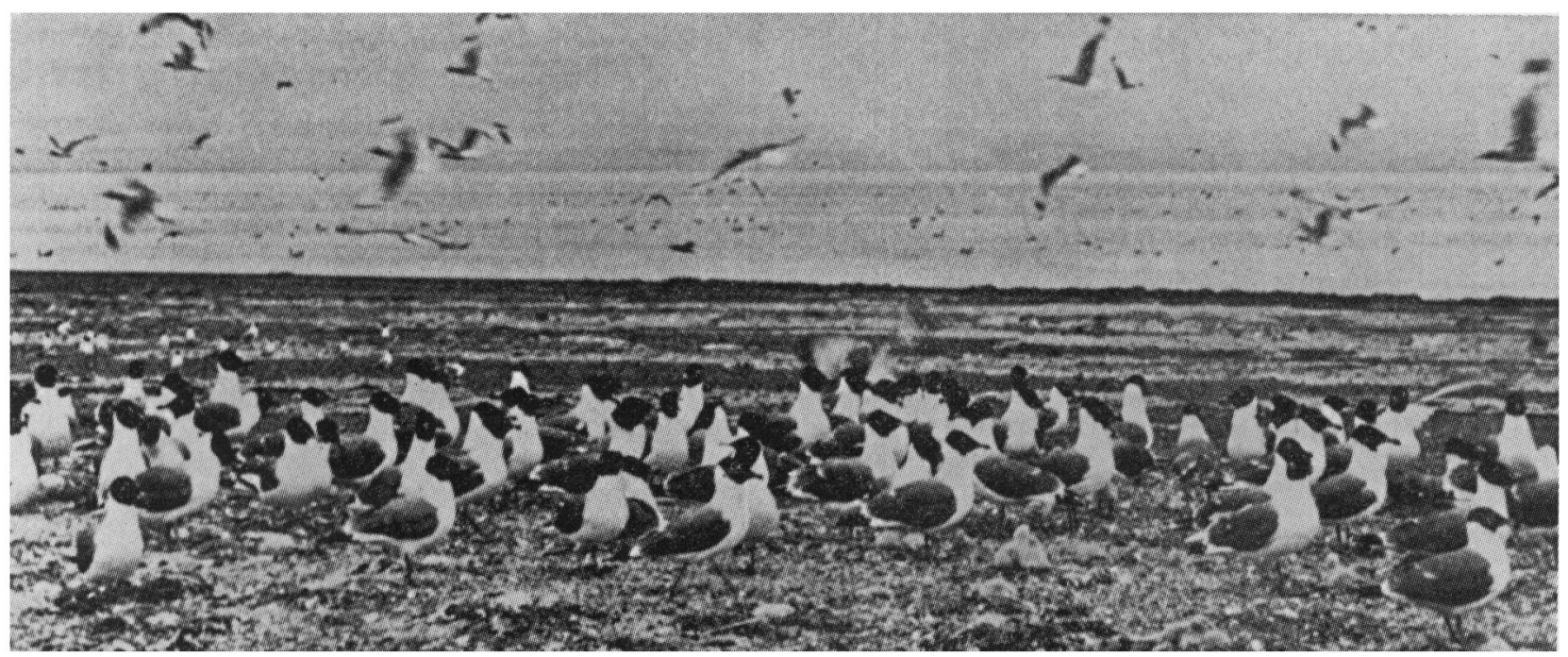

FIG. 7 Nesting gulls on the shore of Lake Kokonor, Chinghai Province (by courtesy of China Reconstructs, Jtine 1972, p. 44). 
(Anon., 1966). Attention is given to ecological studies of bird habits and migration routes and to such economic implications as the domestication and utilization of wild geese.

In this respect, the Chinese follow management ideas borrowed from Soviet scientists who have estimated that the single, large nesting colony of Lesser Snow-geese on Wrangel Island in north-east Siberia could supply 500,000 eggs per year-the equivalent of a poultry farm with 10,000 hens-if the collection and supply to the people in Chukchi National District were organized. It is noteworthy that the first visit from a Soviet ornithologist to study migratory waterfowl as part of a cooperative field project took place recently in the United States, where Lesser Snowgeese winter in Pacific Coast states (Uspenskii, 1966; U.S. Fish and Wildlife Service, 1976).

The Yunnan Provincial Institute of Zoology in south-west China has carried out faunal surveys on both useful and rare species. Rare animals include the Lesser Panda, Takin, Civet Cat, and Monal Pheasant (NCNA, 1 Dec. 1973). Protection is afforded to these and other animals, such as the Snow Leopard and White-lipped Deer, explicitly because they are rare.

However, the degree to which habitat preservation is a part of Chinese wildlife management programmes is difficult to assess. In general, environmental protection is conceived as combining the wise use of resources with pollution control measures (Kuo Huan, 1974). Such an approach is seen to incorporate and integrate both economic and environmental values, and to transform natural ecosystems for the benefit of society. Although habitat preservation is discussed far less frequently than protection from hunting as a method of game management in both official and unofficial statements, natural reserves are mentioned occasionally. The Wanglang Natural Reserve in northern Szechuan, for example, was created in 1965 specifically to protect the habitat of the Giant Panda from encroachment by forestry and other activities (Wanglang Natural Reserve, 1974).

The Reserve holds about 200 of the elusive Giant Pandas in a $277 \mathrm{~km}^{2}$ zone of subalpine coniferous forest and bamboo. Mysterious and largely unknown to people in eastern China, Panda skins figured in commerce of the T'ang (A.D. 618) Dynasty. However, the Giant Panda remained unknown to Europeans until 1869, when Abbé David obtained a skin and described its remarkable appearance, and the first live animal was carried to the United States in 1936. Ten years ago only 15 living specimens had been received in Europe and North America; knowledge of Panda life-history remains incomplete (the first Panda birth in captivity occurred in the Peking Zoo in 1963), and a gift of a Giant Panda has become a lavish gesture in China's external relations (Morris \& Morris, 1966).

Conflicts between hunting interests and the need to preserve animals do occur in China. In 1962, a Forestry Department official criticized over-zealous hunters who 'wantonly killed harmless animals without restraint' by using poisons and explosives. $\mathrm{He}$ protested against the practice of teams from outside Kuangtung Province who came to hunt rare monkeys and baboons on Hainan Island (cf. Fig. 1), where only wolves among local wildlife had been designated for extermination by the State (P'an, 1962).

The plea for preservation because of economic benefits or extreme rarity (therefore, any economic disbenefits are insignificant) lacks the emotional or aesthetic justification for wildlife preservation that bears weight in Western nations. There is nothing approaching Aldo Leopold's 'land ethic', or his appreciation of the hunter's ethos. Transformation of the environment to promote material productivity, especially through the organization of labour-intensive sectors of the economy, is a goal of China's socialist policy. Wilderness areas or others that are underutilized for their soil, water, or wildlife resources, are to be controlled, cultivated, or exploited in some other way. The trend to biological homogeneity that human activities produce in newly-settled areas can be compared with similar current trends towards simplicity and conformity in the social and cultural affairs of the nation. However, there is a growing recognition of the cultural and political values of unusual or unique biotic resources as exemplified by the Giant Panda (Sowerby, 1938). This is one justification for the preservation of an economically valueless species. In this sense, the utilitarian approach to biota can be at least not exploitative, and management decisions about wildlife are in the hands of a comprehensive national agency which oversees implementation of policy.

The smaller scope and different cultural context of wildlife use in China than in many other countries, lend themselves more to management by one comprehensive agency, and such an agency suits the functioning of Chinese government. The State Council of the Central People's Government formulates policy directives on the basis of information and advice from the economic, scientific, administrative, and political offices. These directives are implemented by provincial and local authorities and are general enough to be adjusted to 'fit local conditions'.

It is the Ministry of Forestry in China--as a unit of the Central Government-which carries out directives in the area of wildlife management through provincial and local bureaus. The Ministry convenes national meetings of representatives from all areas where hunting takes place, to plan the organization 
and further use of wildlife (NCNA, 13 Nov. 1963). At lower levels, in order to devise local hunting arrangements, provincial governments are directed to obtain a clear picture of the species composition and distribution of wild animals, and must investigate animal life-histories and behaviour-especially their relationships with agricultural production.

At meetings on the national, provincial, and local levels, a variety of commercial and scientific viewpoints are represented. Although wildlife management objectives tend to be strongly utilitarian and functional in China, the programmes in force do represent a compromise among differing viewpoints. Every discussion on this topic recognized the twin objectives of hunting wild animals and simultaneously protecting useful and rare species.

\section{SUMMARY}

Current trends in the utilization of wildlife in China continue a tradition of satisfying material needs for meat, apparel, and medicinal and other products. Wild animals have been hunted to bolster income from agriculture and to supply the industrial sector of the economy with material goods. Decisions about conserving or protecting animals are therefore based largely upon utilitarian premises. If they decrease agricultural productivity or are harmful to humans, predatory animals are heavily persecuted.

Chinese biologists have followed initiatives, begun in the Soviet Union, of introducing alien animals to areas where they can multiply and be cropped for commercial purposes. Research also continues to be focused on the possible relocation of faunal elements within China, to develop the market for meat and skins.

However, there appears to be a growing concern for preserving certain rare, unusual, and threatened, species because they are unique to China or have beneficial or symbolic value. This concern is likely to increase as studies in animal behaviour, migration, and ecology, demonstrate that significant declines have occurred in the populations of many 'useful' birds and mammals.

\section{References}

Abramov, V. K. \& Pikunov, D. G. (1974). [The Leopard in the Far East of the USSR and its protection] in Biological Abstracts, 59, No. 7621, Jan. 1975.

Ali, Salim A. \& Ripley, S. Dillon (1968). Handbook of the Birds of India and Pakistan. Oxford University Press, London: 8 vols. See pp. 73-4 of Vol. 1, Divers to Hawks.

Allen, Glover M. (1938, 1940). Natural History of Central Asia, Vol. XI. The Mammals of China and Mongolia, Parts 1 and 2. American Museum of Natural History, New York: vii $+1,350$ pp., illustr.

ANon. (1966). Game preserve control station established at Lake Kokonor. Yang-ch'eng Wan-pao, Kuangchou, 15 March 1966; U.S. Joint Publications Research Service, No. 35342, May 1966.
Burmakin, E. V. (1966). Results and prospects of the acclimatization of freshwater fishes in the USSR. Pp. 149-50 in Acclimatization of Animals in the USSR (Ed. A. I. Yanushevich). Israel Program for Scientific Translations, Jerusalem.

Chen, JaCk (1957). Nomad's two-way trail to socialism. People's China, 24, pp. 29-33.

Cheng, Tso-hsin (Ed.) (1964). China's Economic Fauna: Birds. U.S. Department of Commerce, Office of Technical Services, Washington, D.C.: xvi +696 pp., illustr.

Cole, H. H. \& Ronning, Magnar (Eds) (1974). Animal Agriculture. Freeman, San Francisco: v +788 pp., illustr. (see especially pp. 144-7).

Curry-Lindahl, Kai (1972). Conservation for Survival: An Ecological Strategy. Morrow, New York: $\mathrm{v}+335 \mathrm{pp}$.

Darlington, Philip J. (1957). Zoogeography: the Geographical Distribution of Animals. Wiley, New York: xiii +675 pp.

FLerov, K. K. (1952). [Fauna of USSR-Mammals-Musk Deer and Deer.-in Russian.] Academy of Sciences of the USSR, Moscow: Vol. 1(2), i +257 pp., illustr.

Harris, Jennie E. (1947). His perfume stirs the world (Musk Deer). Natural History, 56(2), pp. 68-71, 94.

Kislovsky, D. (1938). The domestic animals of Mongolia: A review. Journal of Heredity, 29(1), pp. 27-32.

Korsakov, G. K. (1966). Results of acclimatization of Muskrats in the USSR. Pp. 75-7 in Acclimatization of Animals in the USSR (Ed. A. I. Yanushevich). Israel Program for Scientific Translations, Jerusalem.

Kuo Huan (1974). Attach great importance to environmental protection work. Hung Ch'i (Red Flag), 277(9), pp. 11-5.

Leopold, Aldo (1933). Game Management. Scribner's, New York: xxi +481 pp., illustr.

Lin, YaO-HuA \& Shen, Chia-chu (1957). The Olunchuns. People's China, 10, pp. 31-4.

Morris, Ramona \& Morris, Desmond (1966). Men and Pandas. Hutchinson, London: vii +223 pp., illustr.

NAsimovich, A. A. (1966). Theoretical basis of the acclimatization of land mammals. Pp. 15-7 in Acclimatization of Animals in the USSR (Ed. A. I. Yanushevich). Israel Program for Scientific Translations, Jerusalem.

New China News Agency (NCNA): numerous references (based variously on Peking, Kuangchou, Sining, Huhehot, or Nanking), and indicated by dates in text.

P'AN, WU-YaO (1962). Please refrain from capturing wild animals wantonly. Nan-fang Jih-pao, Kuangchou, 3 November 1962; Survey of the China Mainland Press (SCMP), No. 2919, 14 February 1963.

PARADISO, John L. (1972). Status Report on Cats (Felidae) of the World, 1971. U.S. Department of Interior, Fish and Wildlife Service, Special Scientific Report-Wildlife, No. 157. Government Printing Office, Washington, D.C.: ii +43 pp.

Pavlov, M. P. (1966). Results of the acclimatization of Nutria in the USSR. Pp. 91-2 in Acclimatization of Animals in the USSR (Ed. A. I. Yanushevich). Israel Program for Scientific Translations, Jerusalem.

Pen, Hung-Shou (1962). Animals of western Szechuan. Nature (London), 196, pp. 14-6.

Rouse, J. E. (1970). World Cattle. University of Oklahoma Press, Norman: 2 Vols, iv + 1,046 pp., illustr; see Vol. 2, pp. 959-70.

SCHAFER, EDWARD H. (1968). Hunting parks and animal enclosures in ancient China. Journal of the Economic and Social History of the Orient, 11, pp. 318-43.

Schaller, George B. \& Simon, Noel M. (1970). The endangered large mammals of Asia. Pp. 11-23 in I.U.C.N. Eleventh Technical Meeting, Vol. 2, Problems of Threatened Species (Ed. C. W. Holloway). International Union for Conservation of Nature and Natural Resources, Morges. 
Seshadri, Balakrishna (1969). The Twilight of India's Wild Life. Baker, London: ix +212 pp., illustr.

SOWER By, ARTHUR DE C. (1914). Fur and Feather in North China. Tientsin Press, Tientsin: i 190 pp., illustr.

Sowerby, Arthur De C. (1918). Sport and Science on the SinoMongolian Frontier. Melrose, London: xvi +295 pp., illustr.

Sowerby, ArThur de C. (1925). The Musk-deer in China. China Journal, 3(12), pp. 651-3.

Sowerby, Arthur de C. (1933). The Tiger in China. China Journal, 18(2), pp. 94-101, 108-9.

Sowerby, Arthur de C. (1938). The lure of the Giant Panda. China Journal, 23(5), pp. 251-4.

Sowerby, Arthur de C. (1940). Nature in Chinese Art. Day, New York: $v+203$ pp., illustr.

TAte, G. H. H. (1947). Mammals of Eastern Asia. Macmillan, New York: $v+366$ pp., illustr.
U.S. Fish and Wildlife Service (1976). Conserving Our Fish and Wildlife Heritage-Annual Report, 1975. U.S. Department of Interior, Washington, D.C.

USPENSKII, S. M. (1966). Prospects for the Reacclimatization of the Snow Goose in the continental tundra of Siberia. Pp. 132-33 in Acclimatization of Animals in the USSR (Ed. A. I. Yanushevich). Israel Program for Scientific Translations, Jerusalem.

WANG, TE-K'UN (1955). The thriving Olunchun Nationality in the Northeast. Kuang-ming Jih-pao, Survey of the Mainland Press, No. 1160, October 11.

Wanglang Natural Reserve (1974). A survey on the Giant Panda (Ailuropoda melanoleuca) in Wanglang Natural Reserve, Pingwu, Northern Szechuan, China. Acta Zoologica Sinica, 20(2), pp. 162-73.

Whitehead, George K. (1972). Deer of the World. Constable, London: $x i+194$ pp., illustr.

\section{Canadian Association for Northern Research Proposed}

At a meeting held during 26-29 February 1976 at Rankin Inlet, Northwest Territories, an arctic settlement on the west coast of Hudson Bay, representatives of fourteen Canadian universities that are active in northern research agreed unanimously to plan a new organization. The Sixth Canadian Universities Northern Scientific Training Conference concluded the three-days Rankin Inlet meeting by appointing a Working Group to report later this year on the best form of organization to meet the universities' needs for collaboration in carrying on northern research and training, and for closer liaison with governments, industry, and northern residents.

The proposed association will be designed to serve the increasing scientific needs of the North and will be something new for Canada. It will be bilingual and reflect the interests and strengths of all regions of the country. An administrative headquarters will be opened in due course.

The demand by governments, private industry, and native organizations, for scientific information, skills, and advice, is growing daily. Canada needs to utilize the scientific resources within its universities more effectively. The new association is intended to facilitate this.

The Working Group met further in Saskatoon, Saskatchewan, in April and in Montreal in May, and will also discuss the role of the association and its headquarters with Federal, Territorial, and Provincial governments, with native organizations, and with private industry. They will bring the plans for the association to the attention of the people of Canada-especially those living in the Arctic and Subarctic-and recommend arrangements for close relations internationally with scientific centres and universities.

The Working Group's Report will be considered at a meeting of representatives of Canadian universities that are active in northern research, which is to be held, by invitation of the University of Alberta's Boreal Institute, at Fort McMurray, Alberta, in December 1976. Founding of the new association should follow soon afterwards.

The association, with its member university centres, institutes, and committees for northern research, is expected to play a significant role in meeting Canada's northern scientific needs and in the long-term development of the North.

\author{
Trevor Lloyd, Chairman of the Working Group \\ Centre for Northern Studies and Research \\ McGill University \\ P.O. Box 6070, Station A \\ Montreal, Quebec, Canada.
}

\section{International Polar Bear Agreement}

The First International Agreement on Conservation of Polar Bears (Thalarctos maritimus) came into force on 26 May 1976 and was widely welcomed. Of the five circumpolar nations, Canada, Norway, and the USSR have ratified the Agreement, which was signed in Oslo on 15 November 1973. The other signatories, Denmark and the USA, are expected to accede in the near future. The Agreement prohibits the hunting, killing, or capturing, of Polar Bears except for bona fide scientific or conservational purposes, or by local people, such as Eskimos, using traditional methods in the exercise of their traditional rights.

This important Agreement crowns the work of the Polar Bear specialist group from the circumpolar nations which was brought together by the International Union for Conservation of Nature and Natural Resources. The group has coordinated research and, as a result of conservation measures already taken on its recommendations in individual countries, the Polar Bear is showing signs of recovery from its widespread decline in numbers which was due largely to killing for fur, trophies, and sport.

An important feature of this agreement commits the parties to protecting the ecosystems of which Polar Bears are an integral part, including their denning and feeding sites and migration routes. These are liable to considerable disturbance from increasing human penetration, especially in the search for oil.

Polar Bears are found only in the Arctic, where they live mainly on seals, although they also eat berries, roots, and shrubby vegetation*. Six separate populations have been identified: Wrangel island-western Alsaka, northern Alaska-northwestern Canada, northeastern Canada-West Greenland, East Greenland, Svalbard-Franz Josef Land, and central Siberia. Details of numbers are not known but the total population is believed to be fewer than 20,000.

\section{PeTer F. R. JACKson, Director of Information World Wildlife Fund 1110 Morges Switzerland.}

* As we noted in 1931 on Akpatok Island, Ungava Bay, where at least several were marooned for the summer but seemed to do very well on the generally sparse limestone vegetation.-Ed. 